\author{
Ksenija Bogetić \\ University of Belgrade \\ Faculty of Philology \\ Belgrade, Serbia
}

\title{
DISCURSIVE METAPHORICAL FRAMES: THE VIOLENCE OVER LANGUAGE FRAME IN SERBIAN AND BRITISH NEWSPAPER DISCOURSE
}

\begin{abstract}
This paper proposes an approach to analyzing systematic metaphorical representations in discourse, introducing the notion of discursive metaphorical frames to capture the different levels of conceptualization and generality that contribute to the social meaning of metaphor. The approach is illustrated through an analysis of metaphorical representations of the position of Serbian/ English language in Serbian and British newspapers, in light of the growing interest in language observable in European public discourses more recently. One conceptualization, based on the metaphor domain of VIOLENCE, is found to stand out in both Serbian and English articles, but analysis of the VIOLENCE OVER LANGUAGE frame shows that it is nevertheless radically different in the two language contexts, reflecting the different ideologies that may shape contemporary media metadiscourses. The value of the proposed approach in revealing the full crossdiscursive metaphorical frame and its more subtle social meanings is discussed.
\end{abstract}

Key words: metaphor, framing, language ideology, newspaper discourse

E-mail address: ksenija.bogetic@gmail.com 


\section{Introduction}

Language is possibly the most seemingly non-sensational topic that has always engaged the popular imagination. From the arrival of the printing press bemoaned as Satan's invention to destroylanguage and communication (Crystal 2001) to the late $20^{\text {th }}$ century public discourse on language and technology in the hands of "idiot teenagers" (Thurlow 2007), the fact that language has provoked "extraordinary surges of passion" (Cameron 1995: 85) many times in history has often been acknowledged by sociolinguists, especially in the anglophone world. The beginning of the new century, however, appears to have brought unprecedented public interest in language across Europe, partly in light of demographic and political changes (see Cameron 2013). In the context of Serbia, the politically longinstrumentalized media discussions on language (Bugarski 1997, 2001, 2013) do seem to be taking on new forms, reflecting new anxieties over the future of language. Even in the context of Britain and the world's major global language, public focus on language use is similarly on the rise, linked to increasing emphasis on "community cohesion" predicated on the use of good English by all citizens (Cameron 2013). In these shifting public discourses, the exact representations of language in the media are of great interest from the sociolinguistic perspective, especially if we understand that metadiscourse often works as a code for discussing more complicated or more sensitive social matters.

One unique insight into language perspectives and ideologies is granted by exploring the way language is discussed using metaphor in public discourse, given that media discourse is highly metaphorical (Krennmayr 2011), and discussions on language are no exception (Argent 2014). Recently, discursive aspects of metaphor use have gained a prominent place in metaphor studies (eg. Cameron \& Deignan 2006, Cameron 2016, Musolff 2006, Semino 2008), as it is increasingly emphasized that metaphor is not just a matter of language and thought, but also of argumentation as well as ideology. In this respect, the discursive representation of language via metaphor in particular contexts is a productive object of analysis, reflecting the specific metaphorical frames (Ritchie 2010, Burgers et al. 2017) within which aspects of language are locally presented.

Still, exploring the metaphorical frames of language in newspaper discourse is a complex task, given the increasingly emphasized conflicting understandings of metaphor and framing, as well as the conflicting views 
of how cross-discursive representations may best be approached in analyses (Semino et al. 2016, Ritchie 2017). In this paper, I aim to address this problem by proposing the notion of discursive metaphorical frames as an appropriate apparatus for capturing the complex functioning of metaphor across discourse. I will draw on it to emphasize the different levels of conceptualization and generality that contribute to the social meaning of metaphor. The approach will be applied in an analysis of metaphorical representations of the national language in Serbian and British newspaper discourse. The newspaper discussions of language and the two-language focus are seen as providing appropriate material in which to illustrate the proposed approach, expected to bring deeper insights into both metaphorical framing in discourse and contemporary language ideologies.

\section{Background: metalanguage and metaphor}

Metalanguage $^{1}$, or talk about talk, has been attracting more scholarly attention recently, as it reveals much about how people view language and its role in their lives (Squires 2010, Jaworski et al. 2004). Still, the relevance of metalanguage for socially oriented scholarship goes far beyond this. In many local and national contexts, questions of language are sparking passionate public debates, which spill into realms that have seemingly little to do with language. Ideologies about language are inseparable from other ideologies regarding social organisation and control, and they draw on the powerful symbolism by which language represents identity, group belonging, social and moral order. In $21^{\text {st }}$ century Europe in particular, public discourse on language has become both widely pervasive and politically salient (Cameron 2013). It is this specific cultural and political significance that discourse on language tends to assume which makes metadiscourse worthy of study.

It has often been noted that discussions on language are a field rich in metaphor, language being a complex abstract phenomenon open to figurative representations and primarily discussed metaphorically (Seargeant 2009, Argent 2014). Metaphor analysis thus provides a good

1 The term "metalanguage" is used in a number of ways in linguistic literature. In this paper, I will use it to refer to those instances where language is explicitly thematized in people's language use (Thurlow 2006, 2007); for many other understandings of metalanguage, see Jaworski et al. 2004. 
path for studying metalanguage, though it has been used to different aims - to provide insights both into how we understand the abstract concept of language itself and into how language is represented in particular discursive contexts.

Metaphorical conceptualizations of language as an abstract phenomenon have long been studied in the philosophy of language and in linguistic theory. The most important early paper in this field of research is Reddy's (1979) study, which argues that the major way in which we conceptualize language and communication is based on the conduit metaphor, i.e. by understanding language as a conduit that carries reified thoughts and feelings (e.g. get your thoughts across). Reddy focused on English language examples, but very similar conceptualizations have been found to operate in Serbian as well (Živanović 2014, Klikovac 2006). Later studies further revealed the complexity of these representations, highlighting some other prominent perspectives. Jean Aitchison (2003) shows that expert discourses on language historically involved several different metaphors, all of which corresponded to the current social theories and world views (including metaphors of CONDUIT, TREE, FAMILY, PLANT and BUILDING). When it comes to folk linguistic discourses, existing findings further point to the prominence of reification metaphors (Seargeant 2009, Blommaert 2008) as well as personification metaphors (Strenge 2012, Đurović 2009, Bogetić 2015).

Another line of research, more akin to the present analysis, has examined the specific representations of language in particular social discourses. Argent (2014) thus stresses that the choice of metaphors in talk about language can reveal what characteristics are ascribed to language and how it is viewed in relation to speakers and society. In her analysis of Russian newspaper metalanguage, she shows that Russian is predominantly conceptualized as ill and infected by Anglo-American influences, and she argues that language matters are instrumentalized in Russian newspapers primarily for the purpose of strengthening the national consciousness. A large body of work has similarly focused on language representations in mass media. In the anglophone world, analyses reveal a major concern about language in digital media as threatening the notions of good communication (Thurlow 2007, Herring 2011). Also, various aspects of political discourse may be productively analyzed via metalanguage and metaphor. For example, Tatjana Đurović identifies several conceptual metaphors dominant in EU discourse, and points to their clear pragmatic 
role in more persuasively highlighting particular sociopolitical stances (e.g. acknowledging the importance of national languages within the $\mathrm{EU}$, or easing the potential members' concerns over losing their national identity).

While this line of research is comparatively smaller, it is clear from existing studies that dominant metaphorical representations in a particular metadiscourse offer a unique view of the dominant language representations and language ideologies. Still, the socially oriented work on metaphor in discourse has generally been more prone to methodological tensions between understandings of conceptual and discursive metaphor, and privileging one over the other has often led to one-dimensional or reductionist accounts. To address this issue, in the present analysis I propose a specific theoretical approach, as discussed in the following section.

\section{Theoretical framework: from conceptual metaphors to discursive metaphorical frames}

In the conceptual metaphor theory (CMT) proposed by Lakoff and Johnson (1980), our conceptual system is shown to be substantially structured by metaphor. Extensive work in this tradition has demonstrated that the way we talk, as well as think and act, is shaped to a great extent by metaphor. In this sense, metaphor is seen as the understanding of one conceptual domain in terms of another: it involves a mapping (or a set of correspondences) from a more concrete, experientially familiar, source domain to a more abstract, target domain. For example, in expressions such as 'Tomorrow is a big day' or 'I enjoy the small things in life', one domain of experience (importance) is understood via another domain of experience (size). In this metaphor, important things correspond to big things, unimportant things correspond to small things, becoming more important corresponds to growing in size, etc.

While Lakoff and Johnson's theory remains a pillar of cognitive linguistics, the past couple of decades have also seen a growing awareness of the discursive importance of metaphor. The appealing premise that metaphor shapes the conceptual structures of our perception of the world has led many researchers to emphasize that metaphor is a "way of thinking and a way of persuading as much as it is a linguistic phenomenon" (Charteris-Black 2004: 22, cf. Lakoff \& Johnson 1980: 155-159). At the 
turn of the century this perspective also engendered a lot of criticism of CMT's reliance on decontextualized and elicited metaphor examples, but these debates now seem to have been abandoned in favour of a more appropriate integrative understanding of metaphor studies.

Partly in response to the challenges of integrating CMT and discourse studies of metaphor, a concept that is currently witnessing renewed interest is that of framing. Most simply put, the contemporary analytical metaphor of a "frame" can be understood as a "way of seeing things", operating in two related senses, as Ritchie (2017) succinctly explains: one is that of a picture frame, calling attention to certain aspects of a situation depicted, i.e. those that are inside the frame, and diverting attention from other aspects of that situation, i.e. those that are outside the frame; the second sense is that of physical structure, representing the bits and pieces that give structure, shape, and strength to a concept. The notion is by no means new, with roots in sociology (Goffman 1974), communication studies (Schön 1993, Druckman 2001, Iyengar 2005), and cognitive semantics (Fillmore 1975), as well as being mentioned in CMT itself (Lakoff \& Johnson 1980: 10-13, Lakoff 2003; though CMT operates on the level of domains). What it promises to bring to studies of metaphor in discourse, however, is a more adequate tool for describing the ways metaphor choices reflect and reinforce particular ways of perceiving issues. To give just one example: if media discussions consistently represent language by drawing on metaphors from the PLANT domain (language blossoming, withering) this can be said to create a frame for understanding language that highlights only some of its properties, particularly those in relation to self-regulation and growth, implying a specific way of reasoning about language - one of natural development, transformation and growth. On the other hand, using MACHINE metaphors, for instance, would bring a whole new frame for thinking about language, one based on regulation and control (see Bogetić 2017). In addition, there may be only some aspects of the PLANT domain that are relevant at the discursive level, e.g. if the metaphorical expressions solely relate to withering away or drying out, and to no other aspects of plant life. What is crucial here is that different aspects of metaphor use can create jointly specific frames for reasoning about abstract issues, reflecting positions that may not be overtly expressed in discourse and may not be adequately captured at the level of conceptual metaphor or conceptual domains only. The term "frame" can be used to capture this 
complex conceptual structure, while "framing" refers to the process of representation building with an impact on reasoning.

However, it is clear even in this brief description that metaphorical framing is still a problematic analytical tool. Metaphorical frames have been related to different levels of conceptual structure and described at different levels of generality, from metaphorical sub-domains (e.g. Sullivan 2013), through structures equivalent to domains (e.g. Croft \& Cruse 2004), to overarching structures built via metaphor (e.g. Musolff 2006). Also, the relationship of metaphorical frames and conceptual metaphor, and of framing and other functions of metaphor has remained rather unclear, though many studies discussing frames seem to avoid references to conceptual metaphor.

This paper adopts a discursive view of metaphorical frames, seen as necessary if we are to describe systematic metaphorical representations across discourse. Specifically, the concept of discursive metaphorical frames (DMF) is proposed as a way to distinguish them from other types of frames, and as a useful theoretical and methodological abstraction for the discursive analysis of metaphor. In relation to existing approaches, its productivity lies in allowing us to capture the full systematic cross-discursive meaning of metaphor, based on the assumption that the meanings of metaphor in discourse include multiple levels of conceptual structure; these may not only involve the conceptual domain, but also particular domain elements and prominent sub-domain roles, which build a frame of reasoning together. Still, the perspective draws on traditions of framing in cognition and communication studies, and is by no means in conflict with traditional approaches to conceptual metaphor. In what follows, I will illustrate the applicability of the DMF approach in describing the systematic multilevel metaphorical meanings relevant across discourse. The metaphorrich media discourse on language is expected to be a good site for such investigation, and the focus on two different language/national contexts may be especially productive when trying to pinpoint the composition of metaphorical frames.

\section{Data and method}

The present analysis draws on a corpus of 100 English and 100 Serbian newspaper articles (approximately 60,000 words in each set). The texts 
were published between 2011 and 2015 in major national daily newspapers: Politika, Blic, 24 Sata, Novosti and Pres (Serbia); The Times, The Guardian, The Daily Mail, The Telegraph and The Independent (UK). The material includes only the texts that directly discuss the Serbian/English language, excluding those written for purely instructional purposes. The corpus is large enough for some basic quantitative observations, but also allows indepth discursive analysis.

The analysis involved three steps: identification of metaphorical expressions to do with language, identification of dominant source domains, and analysis of the discursive metaphorical frames based on the dominant domain(s).

Since the focus is on metaphorical expressions to do with language, the starting point of the analysis was to identify key discourse terms, i.e. those language-related terms in connection with which metaphors were used in the two corpora. They include the following: (i) (srpski) jezik, pismo, govor, izraz, ćirilica, latinica, reč, gramatika in the Serbian corpus, and (ii) (English) language, speech, word, sentence, punctuation, grammar, vocabulary, apostrophe, comma in the English corpus. ${ }^{2}$ Identification of the pertinent metaphorical expressions was then conducted according to the guidelines of the now well-established Metaphor Identification Procedure VU (Steen et al. 2010).

Source domain classification/identification of dominant domains was conducted following the discursive approach of Low and Todd (2009) and the "wisdom of sticking to more specific labels" (Dancynger \& Sweetser, 2014: 52) when classifying domains. While bearing in mind the hierarchical nature of all metaphor (Lakoff \& Johnson 1980), this approach identified only the contextually-specific source domains, rather than broader conceptualizations such as personification or reification.

Finally, upon identification of the dominant, most frequent source domain(s) used in the discussions of language, the analysis turned to exploring these in discourse and describing the full discursive metaphorical frames that they constituted in the two language corpora. The in-depth analysis of discursive metaphorical frames was exploratory and deliberately left partly open at the initial stage, looking into the discursive realizations of the domain-level mappings and the potentially relevant sub-domain elements.

2 Key discourse terms were identified upon an initial reading and re-reading of the whole corpus; the selection comprises terms used at least 10 times in the Serbian/English corpus. 


\section{Results}

\subsection{Analysis of source domains: one stand-out representation}

The metaphorical expressions used in relation to the Serbian and English language in the Serbian and British newspapers (a total of 901 and 739 instances respectively) involve a variety of source domains (60 and 66 identified domains respectively). However, not all of them are of equal discursive importance. Namely, a large majority of source domains are represented with just one or two instances of use (e.g. SPORTS, FOOD, WATER). A few domains are indeed realized with more examples, pointing to some cross-linguistic similarities: in both corpora, language is metaphorically construed via the domains of WEALTH (e.g. the richness of our language, the value of language, enriching language), MACHINE (e.g. the language mechanism, the cogs and bolts language, language breaking down) or BUILDING (e.g. building sentences, the foundations of language). In addition, the English corpus contains expressions from the domain of evolution, not observed in Serbian. However, even these repeated representations occur in 15-30 instances, each comprising about $2 \%$ of the metaphorical expressions in total, which is insufficient for a more thorough discursive analysis using the present corpus.

In fact, only one metaphorical representation is clearly found to be prominent in both datasets - that involving the source domain of VIOLENCE (eg. killing our language, butchering language). It occurs about 130 times in the English corpus and 180 times in Serbian (comprising roughly onefifth of all metaphorical expressions identified), which is more than all the other source domains taken together. What emerges from the quantitative analysis, therefore, is that both Serbian and English newspaper discourse about language are characterized by the prominence of VIOLENCE-based metaphors. Of course, VIOLENCE is a productive conceptual source for representing a variety of phenomena (Charteris-Black 2004, Ritchie 2003), but it has not been observed in existing analyses of metadiscourse.

While the other metaphorical representations may certainly be worthy of study in different types of analysis, we will here focus on VIOLENCE OvER LANGUAGE as the salient discursive metaphorical frame (if cross-discursive systematicity is a criterion, these other representations do not form a DMF in the present sense). The analysis allows us to further illustrate the approach to DMFs and examine the full frame produced in the observed context along with its deeper socio-ideological implications. 
A final note before embarking on the analysis: another pattern that emerges from this preliminary observation is thematic, but nevertheless relevant for understanding the corpus as well as the stand-out DMF. The texts in both corpora tend to discuss not just language in general, but specifically the position of language and language change (a somewhat unexpected finding given the range of language and communication questions that could be of interest for media discussions). These concepts constitute the specific target in many of the metaphorical expressions identified and are certainly central to the VIOLENCE OVER LANGUAGE frame, as will be seen below.

\subsection{Domain-level representations in the VIOLENCE OVER LANGUAGE frame}

Analysis of the metaphorical representations based on the VIOLENCE domain is telling of the general attitudes to the position of language and to language change. Both the Serbian and English newspapers discuss language by drawing on a variety of metaphorical expressions from this domain, contributing to an overall narrative of threat that is rather similar in both contexts. Such representations are clear from the very titles of the articles, which commonly include metaphorical references to beating, general violence or wars and invasions:

S:

(1) Udarali po jeziku (Novosti, 13/8/2011)

(2) Srpski jezik je napadnut sa svih strana (Novosti, 15/01/2012)

(3) Neizdrživo nasilje nad jezičkom kulturom (Politika, 12/08/2012)

(4) Okupacija stranih reči (Novosti, 14/11/2013)

E:

(5) Want to mangle the English language? There's an app for that. (The Daily Mail, 16/6/2012)

(6) Ploddledygook is murdering the English language (The Times, 9/05/2013)

(7) Emoji invasion (The Guardian, 25/06/2015)

(8) War of the words (The Guardian, 26/09/2012)

These are some very typical titles in the material, reflecting what seems to be a general tendency for article titles to be metaphorical - almost half of the titles contain metaphor, and the majority of these are metaphors 
of VIOLENCE. The rhetorical force of titles such as the above comes from the expressivity of the vIOLENCE domain. The type of language phenomena referred to is at first glance very diverse, but all the titles demonstrate a clear conceptual link between violence and non-standard language use/ unwanted language influences. In this conceptual metaphor, the role of a target or victim of violence is mapped onto aspects of language, with great conceptual overlap on the level of metaphorical interpretation between Serbian and English. Within the texts, the description is often more elaborate and extended through several metaphorical expressions from the domain:

S:

(9) Pored tuđica koje su ga opkolile sa svih strana, srpski jezik našao se pred još jačim neprijateljem i uveliko gubi bitku. (24 sata, 25/12/2012)

These metaphorical expressions also carry war associations, where language is seen as a victim ${ }^{3}$ of a war attack, influences over language are the attacker, the introduction of foreign words is besieging, and the attempt to resist language change is a battle. Similar metaphorical analogies are common in the English corpus, based on the same general mappings of LANGUAGE AS A VICTIM OF VIOLENCE and UNWANTED INFLUENCES ON LANGUAGE AS AGGRESSORS. One difference that can be observed between the Serbian and English articles is that even when they employ the same metaphorical representations, these tend to be more frequently and more richly elaborated in the English corpus, often involving intertextually specific images of attack that can be quite dramatic and colourful:

E:

(10) It is the relentless onward march of the texters, the SMS (Short Message Service) vandals who are doing to our language what Genghis Khan did to his neighbours eight hundred years ago. They are destroying it: pillaging our punctuation; savaging our sentences; raping our vocabulary. And they must be stopped. (The Daily Mail, 20/06/2015)

(11) Make no mistake. These are dark times for the English language. The barbarians are at the gates. Right now, marauding grammatical Goths are encircling our linguistic Rome. We must act now to prevent disaster. We must valiantly

3 A single person or a collective body; both interpretations are often possible. 
defend the apostrophe against those who seek to attack her. We must don our grammatical armour and man the linguistic barricades, as an onslaught of grammatical philistinism will soon upon us. (The Daily Mail, 13/01/2012)

The first excerpt presents a very elaborate picture, an entire metaphorical story (Ritchie 2010) of the atrocities of war that language is exposed to. The attackers are presented as vandals, and their language influence is depicted through the implicit metaphor 'what Genghis Khan did to his neighbours eight hundred years ago' that relies on a cultural understanding of the reference. The second excerpt illustrates similar representations, with its opposition of a linguistic Rome and Goths as barbarians seeking to attack. The image of besieging automatically implies the need for audacious defence, emphasized through romantic references to a grammatical armour and linguistic barricades, and to the female-presented apostrophe evoking images of a "damsel in distress" from chivalric romance fiction. Together with the opposition of "us" and "vandals" or "barbarians", the metaphorical image clearly reflects "verbal hygienic" (Cameron 1995) ideological representations of culture and tradition threatened by "barbaric" disrespect for language norms. In this kind of conceptual frame, language change corresponds to war, while those who ignore the rules of language correspond to enemies or vandals/barbarians.

At this point we need to note that the observed metaphorical depictions are by no means only related to source representations of war and military activity, but often involve less specific acts of violence that may or may not be war-related. This includes a range of images of fights, beatings or unspecified acts of violence that may evoke any kind of non-military attack or conflict:

S:

(12) Nasilje koje nad jezičkom kulturom vrše brojni medijski vulgarizmi i jezičke i stilske greške u žutoj štampi [...] prosto je neizdrživo. (Politika, 8/12/2012)

(13) Mogu li strane reči, kao moćno oružje, „ubiti” neki jezik? (Novosti, 09/05/2011)

(14) Živimo u vremenu u kojem jezik trpi i meta je raznih izazova i napada. (Novosti, 09/04/2015) 
E:

(15) We are not alone in the fight against American linguistic domination. (The Telegraph, 12/06/2014)

(16) Mencken argued that [...] his language outgunned ours. (The Daily Mail, 29/5/2012)

(17) It is impossible to record every act of violence done to the English language. (The Daily Mail, 02/05/2014)

In all examples of this kind it is hard to say whether the metaphorical expressions come from the source domain of WAR or individual acts of violence and fighting. This is not about different levels of generality, but about the fact that conceptual sources often have fuzzy boundaries, despite clear conceptual representations. While this kind of metaphor was traditionally linked to the domain of WAR, our analysis shows that this label choice, or a separate WAR grouping, is not justified. What is more, for most people the source notions of VIOLENCE or FIGHT are experientially more basic than those of war (Ritchie 2003). On the whole, this is why the label VIOLENCE is preferred here.

Generally, by examining the domain-level representations in the material, we can observe an overarching metaphor UNWANTED INFLUENCE OVER LANGUAGE IS VIOLENCE, with the various influences over language corresponding to the ATTACKER, and aspects of language corresponding to the ATTACKED. The discursive effect produced is both evaluative and emotional, carrying a negative evaluation of the situation and accentuating an anxiety over language that implies the need to react. This creates a specific frame for looking at the language position and language change that is strangely similar in the two rather different national contexts, possibly in part the result of VIOLENCE being a productive domain for representing competing ideologies in contemporary Western culture (Ritchie 2003). However, this does not mean that the metaphorical use demonstrated above is merely a reflex of a culturally ingrained conceptual metaphor, or that this metaphor creates the same discursive meanings in all contexts. The above examples already suggest that the full frame may be more complex and more interesting in the present data. In particular, some aspects of violence are prominent, while some seem virtually absent (e.g. the idea of a fight between language and its enemy); there are various concepts that map onto the roles of ATTACKER and ATTACKED, or onto VIOLENCE itself. Simply put, what kind of violence is it? Is it the same in the English and Serbian data? Answering these questions may lead us to some more subtle 
ideological meanings that may be locally constructed and locally relevant, and not necessarily evident on the conceptual domain level. In order to explore them, however, the possibility of contrastive models on the subdomain level needs to be taken into account, which will be explored in the following section.

\subsection{Sub-domain representations in the VIOLENCE OVER LANGUAGE frame}

In this segment of the analysis, we look closely at the source and target concepts, the referent roles and focal elements within the violence domain. The underlying assumption is that these sub-domain aspects contribute to the full discursive metaphorical frame and that they may reveal more specific social meanings. In this perspective, a concept of great value is that of metaphor scenarios as developed by Andreas Musolff (2006, 2015), used to represent the level of sub-domain conceptual structures. In brief, Musolff has emphasized that not all aspects of source domains are equally important and equally prominent in discourse; the focal sub-domain elements and mappings can create entire mini-narratives, and the term "scenarios" captures these. Thus, in the violence domain, we can ask e.g. 'what kind of violence?' / 'what kind of attacker?' Importantly, it is these scenarios that link the conceptual side of metaphor with usage patterns in discourse, facilitating descriptions on both cognitive and discursive levels of analysis.

While the VIOLENCE domain is a rich conceptual schema, in the observed Serbian and English newspapers it is realized solely through aspects of the conflict itself and the opposing sides (covering over $95 \%$ of all metaphorical expressions in both datasets; other elements of the domain, e.g. weapons, or truce, are either present in just a couple of instances or absent altogether ${ }^{4}$ ). From the present perspective, these are the elements whose discursive realization deserves further exploration, from the particular representation of violence to the referent roles of the opposing sides.

When it comes to the nature of the violence itself, two scenarios can be clearly observed in both Serbian and English newspapers, labelled as

4 Coding all metaphorical expressions in a separate table at the metaphor identification stage allowed for these observations to be checked quantitatively; still, in the present discussion, the quantitative results will occasionally be mentioned for illustration, though the focus is not on detailed quantitative findings. 
ATTACK and DEFENCE BY OTHERS ${ }^{5}$. Interestingly, the standard source concept of FIGHTING, with two sides opposed in a struggle, is overridden via these conceptualizations. Language is never a side that fights or responds to violence in the conflict, but can only be defended by others. The metaphorical expressions that refer to violence always refer to an ongoing or imminent attack, be it a simple beating, or cruel mutilation, or an invasion/occupation/attack/siege:

S:

(18) Imamo atak na jezik sa praktično najmerodavnijeg mesta. (Politika, 03/07/2013)

(19) Tako i srpski trpi okupaciju od strane engleskog kao lingua franca. (Politika, 10/09/2015)

(20) Svesni smo da je to udar na srpski jezik. (Blic, 11/09/2014)

E:

(21) The violence the internet does to the English language is simply the cost of doing business in the digital age. (The Guardian, 20/05/2013)

(22) I hate to see language butchered like this. (The Guardian, 28/12/2014)

(23) Well done smart phones - you're on your way to fulfilling your mission of murdering the English language. (The Daily Mail, 18/05/2015)

In this kind of frame, DEFENCE becomes an important segment of the narrative, as the expected way to react to ATTACK:

S:

(24) Još je pre devet vekova Stefan Nemanja preporučivao da jezik treba čuvati kao zemlju, kao grad. Ali jezik se ne može braniti veštački merama (Politika, 03/06/ 2011)

(25) Vreme je za akciju spasavanja jezika (Blic, 21/02/2015)

E:

(26) The texters have many more arrows in their quiver than we who defend the old way [of language]. (The Daily Mail, $17 / 12 / 2014)$

(27) However, defenders of the apostrophe are fighting back. (The Times, 04/02/2014)

5 Following Musolff (2006), italics will be used to represent scenarios. 
On the whole, this narrative of "attack and defence" often evokes events of war, though it can refer to any kind of attack and defence of a victimized person. It operates in very similar ways in the Serbian and English texts, activating the meanings usually associated with defending others, such as audacity, moral righteousness, and protection of the weak. The given scenarios bring a novel dimension to the violence metaphors and add a specific moral note to the discussions of language.

What is also noticeable from the above examples is the variety of concepts that take the referent roles of attacker (the internet, media, texting, youth, foreignisms), whereas those of the attacked seem rather uniform as referring to our key discourse units of language, at least at first glance. However, the attempt to classify these in more detail revealed some important differences between the frames in Serbian and British texts.

Importantly, while in the English dataset the attacker role is indeed taken by a range of concepts, without separate scenarios that could be identified by frequency, the target onto which attacker features are consistently mapped in the Serbian newspapers can most adequately be described as foreign influence. These specific mappings create a prominent scenario of a FOREIGN ENEMY, which covers almost $90 \%$ of concepts seen as doing violence to language in the Serbian texts, and which does not feature prominently in the English texts (less than 10\%, mostly references to Americanisms). The data show that this is a fundamental element of the discursive metaphorical frame in the Serbian corpus. The focus seems to be on influences from English or from the ex-Yugoslav nation states, though they can also be various foreign influences and are sometimes left unspecific:

S:

(28) Strane reči „okupirale” su srpski jezik. (Pres, 14/11/2013)

(29) Lingvisti upozoravaju da je pred sve većom navalom engleskog jezika, srpski ugrožen u meri u kojoj su to i drugi jezici. Blic, 21/02/2013)

(30) Na srpski jezik u celini, kao i na srpski narod, obrušili su se i ala i vrana i doveli nas u situaciju da se nemamo kuda okrenuti. Zbog toga Hrvati, kroz istoriju provereni neprijatelji našeg jezika i identiteta, mogu da trijumfuju. (Novosti, 30/07/2011) 
The final example is indicative of another major scenario present in the Serbian corpus and not noted in English. Namely, in a vast number of examples, the role of the victim or the attacked side is mapped onto the target not only of language, but of language and nation together. One in every two or three metaphorical representations mentions the Serbian nation and the Serbian language together as victims. In this LINGUISTICNATIONAL VICTIM scenario, the mapping is extended to include language and nation as a kind of inseparable victim of foreign violence:

S:

(31) Zaperci guše srpstvo i srpski jezik (Novosti, 09/11/2013)

(32) Remetić ocjenjuje da se tamo dešava nasilje i nad jezikom i nad srpskim narodom (Politika, 08/04/2013)

(33) To je i više od ironije, to je greh, jer u raspadu Jugoslavije nisu stradali samo država i narodi, već i jezik (Novosti, 09/11/2013)

Collocations of this kind are very common in the corpus, sometimes fusing metaphorical and literal meanings. This may involve nonfigurative references to actual past wars, creatively mixed with figurative representations of violence over language. In this frame, violence over the language means violence over the nation, as nicely summed up in this quote:

S:

(34) Uzmeš li tuđu reč, znaj da je nisi osvojio, nego si sebe potuđio. Znaj da te je neprijatelj onoliko osvojio i pokorio koliko ti je reči potro i svojih poturio. (Politika, 25/08/2014) ${ }^{6}$

This kind of symbolic association between language and nation is prominent in many examples, often followed by conclusions such as "dokle god živi jezik, [...] živi i narod" (Politika 26/01/2014), and it forms a central part of the metaphorical frame observed in the Serbian newspaper discourse about language. This representation was not noted in the general analysis of mappings in this domain, but became clear in more detailed coding of sub-domain referent roles and scenarios.

6 The quote in the Politika article is from the book Zaveštanje Stefana Nemanje by Mileta Medić. 


\subsection{Implications: VIOLENCE OVER LANGUAGE as a multilevel frame}

The analysis of prominent domains in the corpus has shown that there is a strong tendency in both Serbian and British newspapers to discuss matters of language using the metaphor of VIOLENCE. This is a major similarity in the two media contexts, both in terms of domain frequency and the general conceptual mappings. However, the findings clearly show that metaphorical argumentation based on this domain is not just a reflex of a culturally entrenched conceptual metaphor. The deeper ideological meanings in the two national contexts are uncovered only after considering the prominent elements on the sub-domain level.

Analysis on the sub-domain level highlights the true complexity of the VIOLENCE domain, as a rich schema of relations and elements available for selection in discourse. It is the specific choices made within this domain that crucially contribute to creating social meaning across discourse. In this respect, the elements that are left out may be just as important as those that are highlighted, as illustrated by the noticeable absence of two-sided fighting scenarios and the prominence of ATTACK and DEFENCE scenarios in discussions on language. Using two-language data confirms the relevance of sub-domain representations further, revealing significant cross-linguistic differences despite a similar reliance on the viOLENCE domain. Namely, the scenarios of a FOREIGN ATTACKER and LINGUISTIC-NATIONAL VICTIM are central in the Serbian newspaper metadiscourse, but unnoted in the English texts. Ultimately, analysis at this level shows that the anxiety over language in Serbian print media is to do with anxiety over national identity, while superficially similar concerns in English newspapers are broader and mostly lack the national dimension. Such subtle political or attitudinal meanings are evident only when we consider both the metaphor domain level and sub-domain source to target concepts, scenarios and referent roles.

This is where the notion of metaphorical framing and metaphorical frames becomes particularly useful. As is clear from the present findings, understanding the social meanings of metaphor across discourse requires analysis on multiple levels of conceptual structure, and the notion of discursive metaphorical frames offers an adequate way to capture this kind of overarching representation notable across discourse. The multilevel frame of VIOLENCE OVER LANGUAGE observed in this analysis is a very good illustration of a DMF, reflecting the importance of contrastive submodels in this (or any other) conceptual domain (cf. Musolff 2006). The productivity 
of the VIOLENCE metaphor in contemporary thought makes it even more necessary to explore the full discursive metaphorical frame it creates in a specific context. Its sub-domain scenarios, such as those of ATTACK and DEFENCE found in this analysis, can be powerful rhetorical devices in media and political discourse, highlighting stances or courses of action distinct from those implied by other equally possible scenarios (e.g. a TIGHT FIGHT OF EVEN SIDES Or a TRUCE SCenario). While the VIOLENCE and WAR metaphors have traditionally been widely explored, the cognitive and discursive relevance of such mini-narratives in building overarching frames of reasoning deserve attention in future research.

Finally, at this point, the discursive metaphorical frames identified in the present analysis merit a brief general commentary.

\section{The VIOLENCE OVER LANGUAGE frame and the ideologies of language in contemporary Serbian and British print media}

On the whole, the major discursive metaphorical frame in both Serbian and British newspaper discourse on language is built on the vioLENCE conceptual domain. The presence of metaphorical representations of violence and war in this type of discourse is in itself not hard to explain. The idea of a "just war", with aggressors and victims as protagonists, has long been recognized as entrenched not only in media discourse, but in the sociopolitical paradigm of the western world (Burns 2011, Lakoff \& Johnson 1999). The general concerns over language also figure in other European languages (Argent 2014, Cameron 2013), so thematic similarities are not surprising. However, the frequency of metaphorical expressions from this particular domain in both language contexts and their domination over other equally available metaphorical representations (e.g. language change as a competition, a complex system, a journey) point to important, and similar, tendencies of language ideologies in Serbia and Britain.

Most notably, in both sets of data the full discursive metaphorical frame implies an imminent threat to language that needs to be taken seriously. While the metaphorical use involves a wide range of expressions, they all contribute to a master narrative of language being in danger but unable to resist or defend itself. Evocative images of one-sided violence add a dash of sensationalism to the otherwise relatively un-newsworthy topic of language change (Argent 2014), with strong agenda-setting effects instructing the 
readers to think about language matters more seriously. Adopting this frame can have actual consequences in the social world, though it is not entirely clear what the solution to the problems described should be. The DEFENCE of language may come from speakers themselves, but along with the ATTACK scenario may also imply the need for more regulation and control and work to justify stricter language policy in the coming years (as potentially evidenced in e.g. language requirements for citizenship in Britain, or the stricter enforcement of the Cyrillic script for official use in Serbian).

Importantly, as clearly felt in many of the above examples, this frame echoes "verbal hygienic" (Cameron 1995) debates over the nature and state of language, where the order of language corresponds to the order of society; "fixing" language thus becomes a symbolic way of "fixing" society. However, despite some striking similarities between the two language data, a deeper analysis of metaphorical frames has shown that the verbal hygienic language ideologies in these two national contexts are very different. In fact, two fundamentally different metaphorical frames feature in Serbian and English newspapers.

In Serbian newspaper metadiscourse, language-related metaphorical descriptions are centrally interlaced with an internal-external dimension of the national and the foreign. This is implicitly felt in most examples of metaphor use, but can be identified in scenarios of FOREIGN ATTACKER and LINGUISTIC-NATIONAL VICTIM that clearly stand out in the corpus. Such conceptualisation slants the entire frame of language change, as scenarios rarely operate in isolation from one another - in the Serbian texts, unwanted influence on language is crucially conceptualized as a foreign enemy of the nation. The frame carries strong emotional and moral implications, naturalizing the need to halt the external language influences that threaten national identity. In a way, the prominence of this perspective in the Serbian data and its absence in the British corpus needs to be understood against the local political backdrop, particularly in the context of globalization and the influences of English over other languages. As many examples suggest, it must also be seen in the context of heavily mediatized debates on language, language development and language naming in ex-Yugoslav nation states (Bugarski 2001, 2013), and the adversarial relations that still permeate their popular discourse. Linking the frame to the continuing discourse of war and conflict is nevertheless somewhat reductionist, although the many examples of overlapping literal and metaphorical meanings (such as the "killing our people and language" representations) 
show that traces of non-figurative war representations do play a part in metaphorical construction of the Serbian language situation. In particular, what this metaphorical frame reflects is the symbolic view of language as a factor uniting the "imagined community" of the nation (Anderson 1991) and distinguishing it from other nations. In this respect, it is also worth noting that the dominance of the broader vIOLENCE frame gives the discourse a different social and emotional meaning from other possible representations of threats to language and nation, such as the frame of ILLNESS found to predominate in contemporary media representations of the Russian language and nation "infected" by anglophone influences (Argent 2014).

While the underlying impact of the VIOLENCE OVER LANGUAGE frame in Serbian newspapers is thus fundamentally about anxiety over Serbian national identity, an equivalent association is not noted in English newspapers. Contrary to some recent findings on British metalanguage practices reflecting a growing anxiety over Britain's demographic changes, immigration and its position in the global order (Cameron 2013), current newspaper discourses on language do not seem to centre primarily on questions of the national and the foreign. While the metaphors include sporadic references to foreign, mostly American and sometimes migrant influences, such examples are a small minority. The notions that take the ATTACKER role in the corpus include a diverse mix of references to technology, new language forms and speakers themselves, especially youth or the "uneducated". While none of these are found to form a prominent scenario in the present material, they do point to potential links between language and broader social concerns, always in relation to an imagined "other". One such concern is the anxiety over rapid technological developments, recently argued to have formed a novel extension of standard language ideology in Britain, in what could be seen as a form of digital normative linguistics (Heyd 2012). The youth are one notable "other" in this ideological framework (cf. Thurlow 2007), seen as doing violence to language through technology-linked practices that threaten conventional linguistic and communicative norms. Finally, the class dimension that is clear in references to the less educated, the less refined, "barbarians" and "illiterates" intertwines with many of these metaphorical representations. What can be concluded at least from newspaper metaphor use is that the British metalanguage reflects a diversely oriented moral panic (Thurlow 2007) about social decay and declining standards, including society- 
internal age and class dimensions, but with no notable emphasis on nation and the national, at least in the time period analysed.

More broadly, the analysis of metaphor and metalanguage confirms the view that language ideologies are never about language alone (Woolard 1998). Discussions of seemingly trivial issues of language often function as a code for expressing various social concerns that may be more sensitive and harder to discuss overtly. From this perspective, differences in the framing of language change in Serbian and British newspapers can be seen as a reflex of the differences in the two political and media cultures. Nevertheless, the intriguing similarities most notably highlight the importance of some imaginary Other as a threat to language, which can be instrumentalized in various ways, but is likely to represent a major feature of all metadiscourse in the public sphere.

\section{Concluding remarks}

On the whole, the analysis of the violence over LANGUAGE frame in Serbian and British newspapers has revealed the full complexity of metaphorical frames in discourse, seen to function as a composite mosaic, one in which a different selection and combination of pieces could have formed a very a different image. The proposed approach to discursive metaphorical frames has proven productive in capturing such systematic, multi-level structures that are prominent across discourse, and is shown to be a useful theoretical abstraction among the still conflicting understandings of metaphor and framing. While the approach is yet to be applied and tested in other types of discourse, it is hoped that the present discussion provides a step towards more nuanced methodologies for analyzing metaphor in the social context.

\section{References}

Aitchison, J. (2003). Metaphors, models and language change. Motives for Language Change, 39-53.

Argent, G. (2014). Linguistic neuroses, verbal bacteria and survival of the fittest: Health and body metaphors in Russian media discussions about foreignisms. Language \& Communication, 34, 81-94. 
Blommaert, J. (ed.) (1999). Language ideological debates (Vol. 2). Berlin: DeGruyter.

Bogetić, K. (2017) Language is a beautiful creature, not an old fridge: Direct metaphors as corrective framing devices. Metaphor and the Social World, 7(2), 190-212.

Burgers, C., E. Konijn and G. Steen (2016). Figurative framing: Shaping public discourse through metaphor, hyperbole, and irony. Communication Theory, 26(4), 410-430.

Bugarski, R. (1997). Jezik u društvenoj krizi. Beograd: Čigoja štampa.

Bugarski, R. (2001). Language, nationalism and war in Yugoslavia. International Journal of the Sociology of Language, 69-88.

Bugarski, R. (2013). Jezička politika i jezička stvarnost u Srbiji posle 1991. godine. U: Jezik između lingvistike i politike. Vesna Požgaj Hadži, ur. Beograd: XX vek, 91-111.

Cameron, D. (1995). Verbal Hygiene. London: Routledge.

Cameron, D. (2013). The one, the many, and the Other: Representing multi-and mono-lingualism in post-9/11 verbal hygiene. Critical Multilingualism Studies, 1(2), 59-77.

Cameron, L. (2016). Mixed metaphors from a discourse dynamics perspective. Mixing Metaphor, 6, 17.

Cameron, L. and A. Deignan (2006). The emergence of metaphor in discourse. Applied Linguistics, 27(4), 671-690.

Cameron, L., R. Maslen, Z. Todd, J. Maule, P. Stratton and N. Stanley (2009). The discourse dynamics approach to metaphor and metaphorled discourse analysis. Metaphor and Symbol, 24(2), 63-89.

Cameron, L. and R. Maslen (2010). Metaphor Analysis: Research Practice in Applied Linguistics, Social Sciences and the Humanities. New York: Equinox.

Charteris-Black, J. (2004). Corpus Approaches to Critical Metaphor Analysis. London: Macmillan.

Croft. W. and D. A. Cruse (2004). Cognitive Linguistics. Cambridge: Cambridge University Press.

Crystal, D. (2001). Language and the Internet. Cambridge: Cambridge University Press.

Druckman, J. (2001). On the limits of framing effects: Who can frame? Journal of Politics, 63(4), 1041-1066. 
Đurović, T. (2009). "Unity in diversity". The conceptualisation of language in the European Union. Facta Universitatis - Linguistics and Literature, 7(1), 47-61.

Entman, R. (1993). Framing: Toward clarification of a fractured paradigm. Journal of Communication, 43(4), 51-58.

Fillmore, C. (1976). Frame semantics and the nature of language. Annals of the New York Academy of Sciences, 280(1), 20-32.

Goffman, E. (1974). Frame Analysis: An Essay on the Organization of Experience. New Haven: Harvard University Press.

Iyengar, S. (2005). Speaking of values: The framing of American politics. The Forum, (3)1, 8-16.

Jaworski, A., N. Coupland and D. Galasinski (eds) (2004). Metalanguage: Social and Ideological Perspectives. Berlin: DeGruyter.

Klikovac, D. (2006). Semantika predloga: studija iz kognitivne lingvistike (2. izd.). Beograd: Filološki fakultet.

Krennmayr, T. (2011). Metaphor in newspapers. PhD thesis, retrieved June 1 2017, http://dare.ubvu.vu.nl/bitstream/handle/1871/19774/ table? sequence $=2$.

Lakoff, G. (2008). The Political Mind: Why You Can't Understand 21stcentury Politics with an 18th-century Brain. London: Penguin.

Lakoff, G. and M. Johnson (1980). Metaphors We Live By. Chicago: University of Chicago Press.

Lakoff, G. and M. Johnson (1999). Philosophy in the Flesh. New York: Basic Books.

Musolff, A. (2006). Metaphor scenarios in public discourse. Metaphor and Symbol, 21(1), 23-38.

Musolff, A. (2015). Dehumanizing metaphors in UK immigrant debates in press and online media. Journal of Language Aggression and Conflict, 3(1), 41-56.

Ottati, V., R. Renstrom and E. Price (2014). The metaphorical framing model: Political communication and public opinion. In M. Landau, M. Robinson and B. Meier (eds.), The Power of Metaphor. Washington: APA, 179-202.

Reddy, M. (1979). The conduit metaphor. In Ortony, A. (ed.) Metaphor and Thought, (pp.285-324), Cambridge: Cambridge University Press.

Ritchie, D. (2003). "Argument is War" - Or is it a game of chess? Metaphor and Symbol, 18(2),125-146.

Ritchie, D. (2010). "Everybody goes down": Metaphors, stories, and simulations in conversations. Metaphor and Symbol, 25(3), 123-143. 
Ritchie, D. (2017) A note about meta-metaphors. Metaphor and the Social World, 7(2), 291-299.

Semino, E. (2008). Metaphor in Discourse. Cambridge: Cambridge University Press.

Semino, E., Z. Demjen and J. Demmen (2016) An integrated approach to metaphor and framing in cognition, discourse, and practice, with an application to metaphors for cancer. Applied Linguistics, 28, 1-22.

Seargeant, P. (2009). Metaphors of possession in the conceptualisation of language. Language and Communication, 29(4), 383-393.

Schön, D. (1993). Generative metaphor: A perspective on problem-setting in social policy. In: Ortony, A. (ed.), Metaphor and Thought, Cambridge: Cambridge University Press, 137-163.

Squires, L. (2010). Enregistering internet language. Language in Society, 39(4), 457-492.

Steen, G., A. Dorst, J. Herrmann, A. Kaal, T. Krennmayr and T. Pasma (2010). A Method for Linguistic Metaphor Identification: From MIP to MIPVU. Amsterdam: Benjamins.

Strenge, G. (2012). Mediated metadiscourse: Print media on anglicisms in post-Soviet Russian. PhD thesis, retrieved May 1 2017, https://www. era.lib.ac.uk/handle/1842

Sullivan K. (2013). Frames and Constructions in Metaphoric Language. Amsterdam: Benjamins.

Thurlow, C. (2007). Fabricating youth: New-media discourse and the technologization of young people. In: S. Johnson and A. Ensslin (eds), Language in the Media: Representations, Identities, Ideologies. London: Continuum, 213-233.

Woolard, K. A. (1998). Introduction: Language ideology as a field of inquiry. In: B. B. Schieffelin, K. A. Woolard and P. V. Kroskrity (eds), Language Ideologies: Practice and Theory. Oxford: Oxford University Press, 3-47.

Živanović, D. (2014) Konceptualizacija jezika pomoću metafore provodnika u srpskom jeziku u poređenju s engleskim. Prilozi proučavanju jezika, $45,59-71$.

Received: 6 November 2017

Accepted for publication: 31 January 2018 
Ксенија Богетић

\title{
ДИСКУРСНИ МЕТАФОРИЧКИ ОКВИРИ: НАСИЉЕ НАД ЈЕЗИКОМ У СРПСКОМ И БРИТАНСКОМ НОВИНСКОМ ДИСКУРСУ
}

\begin{abstract}
Сажетак
У овом раду предлаже се приступ за анализу систематичних метафоричких представа на нивоу дискурса, увођењем појма дискурсних метаборичких оквира, којим се наглашавају различити нивои концептуализације и општости који сачињавају друштвено значење метафоре. Приступ је илустрован кроз анализу метафоричких представа положаја језика у српском и британском новинском дискурсу, посматраних у светлу појачаног интересовања за језик које се може приметити у јавним дискурсима у Европи у скорије време. Анализа показује да се и у српским и у енглеским новинама издваја једна метафоричка представа, заснована на домену нАсиљА, али да се оквири нАсиљА нАд Јвзиком радикално разликују у дата два језичка контекста. Вредност предложеног приступа за описивање целокупног метафоричког оквира и његових дубљих друштвених значења разматрана је на основу добијених резултата.
\end{abstract}

Кључне речи: метафора, језик, новински дискурс, српски, енглески, дискурсни метафорички оквир 